\title{
A Review on CYP11A1, CYP17A1, and CYP19A1 Polymorphism Studies: Candidate Susceptibility Genes for Polycystic Ovary Syndrome (PCOS) and Infertility
}

\author{
Roozbeh Heidarzadehpilehrood ${ }^{1}$ (D), Maryam Pirhoushiaran ${ }^{2}$, Rasoul Abdollahzadeh ${ }^{2}$, Malina Binti Osman ${ }^{3}$ (D), \\ Maryam Sakinah ${ }^{1}$, Norshariza Nordin ${ }^{4, *}$ (D) and Habibah Abdul Hamid ${ }^{1, *}$
}

check for updates

Citation: Heidarzadehpilehrood, R.; Pirhoushiaran, M.; Abdollahzadeh, R.; Binti Osman, M.; Sakinah, M.; Nordin, N.; Abdul Hamid, H. A Review on CYP11A1, CYP17A1, and CYP19A1 Polymorphism Studies: Candidate Susceptibility Genes for Polycystic Ovary Syndrome (PCOS) and Infertility. Genes 2022, 13, 302. https://doi.org/10.3390/ genes13020302

Academic Editor:

Katarzyna Ziemnicka

Received: 15 December 2021

Accepted: 25 January 2022

Published: 5 February 2022

Publisher's Note: MDPI stays neutral with regard to jurisdictional claims in published maps and institutional affiliations.

Copyright: (C) 2022 by the authors. Licensee MDPI, Basel, Switzerland. This article is an open access article distributed under the terms and conditions of the Creative Commons Attribution (CC BY) license (https:// creativecommons.org/licenses/by/ $4.0 /)$
1 Department of Obstetrics \& Gynaecology, Faculty of Medicine and Health Sciences, Universiti Putra Malaysia Serdang 43400, Malaysia; roozbeh.heidarzadeh@gmail.com (R.H.); maryam.rom@upm.edu.my (M.S.)

2 Department of Medical Genetics, School of Medicine, Tehran University of Medical Sciences, Tehran 1417613151, Iran; maryam.pirhoushiaran@gmail.com (M.P.); rasoul142857@gmail.com (R.A.)

3 Department of Medical Microbiology, Faculty of Medicine and Health Sciences, Universiti Putra Malaysia, Serdang 43400, Malaysia; malinaosman@upm.edu.my

4 Department of Biomedical Sciences, Faculty of Medicine and Health Sciences, Universiti Putra Malaysia, Serdang 43400, Malaysia

* Correspondence: shariza@upm.edu.my (N.N.); habib@upm.edu.my (H.A.H.)

Abstract: Polycystic ovary syndrome is a multifactorial condition associated with reproductive and endocrine organs and might cause infertility and metabolic abnormalities in childbearing age. PCOS seems to be a multifactorial disorder resulting from the combination of several genetic and environmental factors. Little research has been conducted to date on the impact of polymorphisms in infertility. We aim to review the appearance of polymorphisms in females of diverse ethnicities and their effect on infertility in the population with polycystic ovary syndrome. There have been numerous reports of the importance of the steroidogenesis pathway and genetic variants in PCOS pathogenesis. The most important genes that play a role in the aetiology of PCOS are CYP11A1, CYP17A1, and CYP19A1. We evaluated the occurrence of polymorphisms in various ethnicities in the CYP11A1, CYP17A1, and CYP19A1 genes and their efficacy on increasing PCOS risk with infertility. Our findings revealed that polymorphisms in various ethnicities are associated with the risk of PCOS with infertility. Although conflicting results regarding CYP11A1, CYP17A1, and CYP19A1 polymorphisms and their influence on PCOS with infertility have been reported in a small number of papers, the authors feel this may be attributable to the sample size and ethnic composition of the examined populations. In conclusion, our study strongly suggests that the CYP11A1, CYP17A1, and CYP19A1 genes might significantly enhance the probability of developing PCOS with infertility.

Keywords: genetic polymorphism; hyperandrogenism; infertility; steroidogenesis; PCOS

\section{Introduction}

PCOS is a multifactorial disease caused by both genetic and environmental factors and leads to various symptoms [1]. Polycystic ovary morphology (PCOM), menstrual irregularities, and hyperandrogenism (HA) are the diagnostic features of females with PCOS [2]. This condition can be diagnosed based on the Rotterdam criteria or (NIH) National Institutes of Health consensus [3]. Female infertility, diabetes mellitus, hypertension, dyslipidaemia, obesity, and obstructive sleep apnoea are all increased risks for women who have polycystic ovarian syndrome [4]. Women with PCOS have an 11-fold increase in the prevalence of metabolic syndrome than age-matched controls, and these complications can eventually lead to cardiovascular disorders such as myocardial ischemia or infarction and an acute coronary syndrome that can be deadly [5]. In addition to infertility, women with PCOS also have an increased risk of gynaecological problems, including abnormal uterine bleeding and oligomenorrhea, which can ultimately cause uterine/endometrial cancer [6]. 
In addition, they are also at risk of developing psychological disturbances such as anxiety, depression, and eating disorders, which could be due to the physical manifestations of hyperandrogenism, such as hirsutism, male body configuration, and obesity $[7,8]$. The prevalence of PCOS varies, ranging from 4-20 percent depending on various subpopulations that are influenced by the environmental conditions and genetic variations [9]. Anovulation is one of the most significant reasons for infertility in females [10]. Women with PCOS commonly having anovulation with irregular menstrual cycles and sometimes with regular menses. PCOS intricates hormonal imbalances, mainly excessive androgen levels that possibly cause the anovulation [11]. Hyperandrogenism and anovulation have a critical aspect in infertile women with PCOS. Epidemiological data recommend that PCOS causes a high prevalence of ovarian dysfunction and anovulation, where both of these conditions are positively correlated with a progressive chance of infertility [12]. Women with polycystic ovary syndrome appear to experience various conditions during pregnancy, including abortion, preterm delivery, and intrauterine death or stillbirth [13,14].

PCOS is estimated to have a heritability of 70 percent however the genetic loci linked to it so far accounts for just 10 percent of that; on the other hand, increasing research suggests that altered epigenetic and developmental planning due to the hormonal imbalance of the uterine environment might play a role in developing PCOS [15,16]. Numerous studies on the effect of offspring susceptibility to metabolic diseases and obesity $[17,18]$, as well as epigenetic modifications [19], such as DNA methylation, oxidative stress, and vascular diseases, on intergenerational and transgenerational inheritance have been conducted on non-human animals [20]. Overall, the evidence suggests that epigenetic changes occur during foetal life and may have an impact on the developmental origins of PCOS. This is based on the assumption that there is a critical time interval of foetal susceptibility beginning in early-to-mid-gestation when developmental programming occurs [21]. Moreover, researchers performed genome-wide DNA methylation profiling and RNA sequencing on ovarian tissue in both third-generation and control PCOS-like mice to determine their methylation patterns. The results demonstrate that the transfer of PCOS features to future generations happens via an altered environment of DNA methylation, and they suggest the use of methylome markers as a potential diagnostic landmark for the syndrome [22]. Animal models of prenatal testosterone treatment support clinical studies of PCOS women by inducing permanent PCOS-like phenotypes characterized by LH hypersecretion due to reduced steroid negative feedback, hyperandrogenism, ovulatory dysfunction, and impaired glucose-insulin homeostasis. These studies provide insights into when developmental programming occurs during human development, how placental function alters the maternal-foetal relationship to affect foetal growth, and when penetrance occurs. The improvement of the endocrine-metabolic health of PCOS women in order to eliminate their likelihood of gestation complications may have the ability to diminish intergenerational susceptibility to PCOS and the associated metabolic abnormalities in their offspring [23]. There is still much to learn about the intricate interplay of the genome, epigenome, and environmental variables. It is incredibly difficult to separate and trace the impact of each of these elements through generations, particularly in humans [24].

In addition to epigenetic studies, many studies have been conducted to decipher the genetic nature of PCOS. In addition, a number of studies have looked at the link between significant clinical aspects of PCOS and GWAS-identified variants in the last several years $[25,26]$. The goal of the PCOS GWAS loci analysis is to provide insight on the mechanism by which the risk of SNPs may impact the aetiology of PCOS status and, ultimately, to improve treatment outcomes. Following these studies, it appears that the genes DENND1A and TOX3, as well as the genes LHCGR, AMH, AMHR2, THADA, and INSR, are the most important genes in the susceptibility of PCOS. Genetic variations in the previously mentioned genes may be involved in several pathways, including insulin resistance, the dysregulation of androgen and gonadotrophins, and metabolic disorder-related pathways in PCOS pathogenesis [25-27]. There is ample evidence that polycystic ovary syndrome is an intrinsic syndrome, and in most of its clinical symptoms such as obesity and diabetes, 
traces of genetic variation might be seen [28]. The occurrence of alterations in the genes HOXA-10 and HOX-11 in women with polycystic ovary syndrome affects endometrial reception and might risk infertility with implantation failure $[29,30]$. Recent studies have shown that polymorphism in the FSHR gene is significantly associated with PCOS [31]. Even though the function of hereditary pathways in infertility is unequivocally accepted, genetic factors included within the aetiology of female infertility have not been thoroughly demonstrated presently. One of the most significant reasons for infertility with PCOS is the alteration and point mutation in genes involved in biochemical pathways, and one of the key pathways associated with infertility problems is steroidogenesis [32]. Steroidogenesis pathways represent an important topic to study because some genetic variants involved in hypothalamic-pituitary depletion and the gonadotropin receptor have been found to change in women with infertility issues. These changes can interfere with pathways such as androgens and ovulation, which may cause hyperandrogenism and ovulatory dysfunction, making them susceptible candidates worth examining. It is imperative to understand the genes involved in the steroidogenesis pathway. This review summarises and discusses the recent investigation of genetic pathways that have been associated with infertility among PCOS patients. We have chosen the genetic polymorphism of the genes involved in the steroidogenesis pathway as the candidate genetic variants that are susceptible to infertility between females with PCOS, focusing on CYP11A1, CYP17A1, and CYP19A1.

\section{Biochemical Pathways in PCOS}

Due to the polygenic nature of polycystic ovary syndrome, numerous biochemical pathways with various genes have been identified. Many studies have shown the impairment of androgen and ovulation pathways in women with PCOS, resulting in hyperandrogenism and ovulatory dysfunction. Among these biochemical pathways are genes associated with PCOS, including insulin secretion (e.g., INSR, IRS-1, INS), chronic inflammation (e.g., TNF- $\alpha$, IL-6), coagulation cascade and complement (e.g., VWF), signalling (e.g., $A M H$, LHCGR, INS, ADIPOQ), cancer (e.g., MMP, AR1, INS), and steroidogenesis (e.g., CYP11A1, CYP17A1, CYP19A1) pathways [33,34].

\section{Ovarian Steroidogenesis}

Steroidogenesis is a sequential process that converts cholesterol to bioactive compounds in steroidogenic-specific tissues under the control of certain steroidogenic enzymes. The adrenal cortex and the ovary are two examples of steroidogenic specialized organs that produce hormones that govern a variety of reproductive, endocrine, and metabolic activities in women, as well as fertility maintenance. As a result, a disruption in steroidogenesis has been linked to a variety of disorders, including polycystic ovarian syndrome. Therefore, understanding such disorders may provide essential insights for advances in infertility treatment among women with PCOS. Steroid hormones biosynthesis, including mineralocorticoids, progestins, androgens, oestrogen, and glucocorticoids, are conducted by the enzymes that are known as steroidogenic enzymes that constitute steroid reductases hydroxysteroid dehydrogenases (HSDs) and particular cytochrome P450 enzymes (CYPs) [35]. Steroidogenesis in the ovary starts with cholesterol modification and progresses sequentially to progestin, androgen, and oestrogen, all of which are required for subsequent processes synthesizing steroid hormones. These hormones are subsequently delivered into the blood circulation, where they exert their effects on both the peripheral (PNS) and central nervous systems (CNS) [36]. The synthesis of steroid hormones and the maturation of oocytes promote the maintenance of female reproductive tissues [37]. In the ovary, under the influence of the luteinising hormone $(\mathrm{LH})$, cholesterol is converted to pregnenolone by CYP11A1, once bound to the interior layer of mitochondria in theca cells [23]. The CYP17A1 gene converts pregnenolone to 17 hydroxypregnenolone and 17 hydroxypregnenolone to dehydroepiandrosterone (DHEA) as a result of androgen amalgamation captured within the thecal cells containing receptors to LH [24]. Follicle-stimulating hormone (FSH) is required for the CYP19A1 aromatase to produce oestrogen in the granulosa cells. Oestrogens 
have a crucial part in controlling the ovary's function. The mechanism of action of ovarian steroidogenesis is shown in Figure 1. Understanding these steroidogenesis pathways inside the ovary may give key information on the essential molecular regulators that regulate the signalling mechanism in ovarian cells, most notably in hyperandrogenism, ovulation, and fertility.

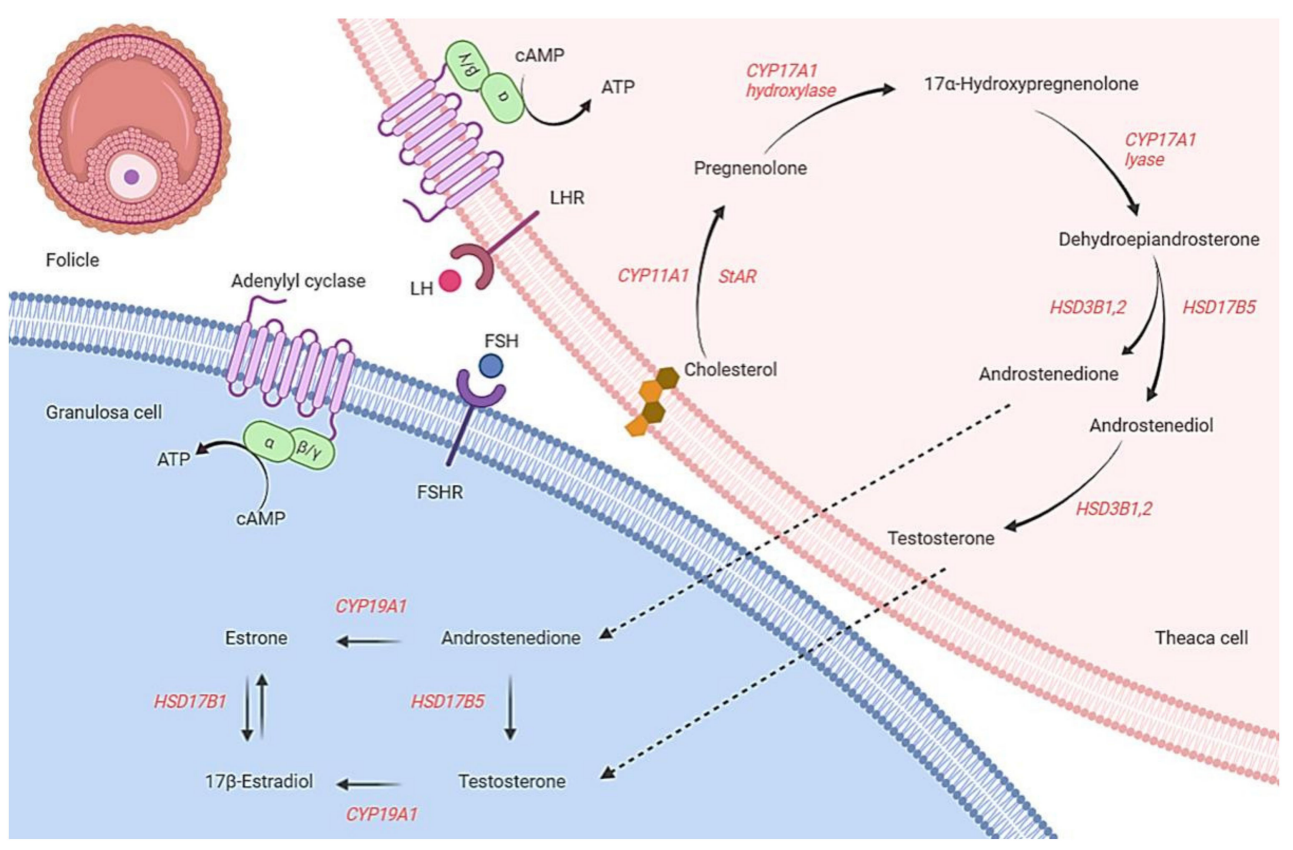

Figure 1. The red colours represent relevant genes in the female ovaries' steroidogenesis process; cholesterol in the theca and granule cells' membranes is the first precursor to convert to pregnenolone. One of the most significant processes for the production of sex hormones in women is steroidogenesis, which occurs in the theca and granulosa organs. Theca cells synthesise the required sex steroid hormones and use steroid enzymes to convert cholesterol to 17-b estradiol. LH—luteinizing hormone; StAR—steroidogenic acute regulatory protein; CYP11A1—cytochrome P450 11A1 (cholesterol side-chain cleavage enzyme); FSH—follicle-stimulating hormone; CYP19A1cytochrome P450 19A1 (aromatase).

\section{CYP Genes and PCOS with Infertility}

Numerous studies have confirmed that hyperandrogenism is one of the most prominent clinical features reported in patients with polycystic ovary syndrome associated with heterogeneous phenotypes with diverse genetic variants. These situations, which involves an enzyme deficiency in the steroidogenesis pathway, is considered a prognosis for PCOS [38]. A subset of the CYP genes encodes enzymes involved in the process of steroidogenesis biosynthesis. Among them, the majority of research has focused on the CYP19A1, CYP17A1, and CYP11A1 genes [39]. The CYP19A1 gene encodes an enzyme that is a member of the cytochrome P450 family. The cytochrome P450 family of enzymes is involved in the synthesis of lipids, steroids, cholesterol, and the metabolism of drugs. Cytochrome P450 protein is located on the endoplasmic reticulum network, and catalysis is the final stage of steroid biosynthesis. Mutation in this gene might reduce or increase aromatase activity. The evaluation of phenotypes associated with abnormalities indicates the ambivalent function of oestrogens in growth and differentiation, as well as a sex steroid hormone [40]. The CYP17A1 gene, which encodes the cytochrome P450 protein, catalyses multiple reactions including the production of steroidogenesis, androgens, glucocorticoids, and progestins. Mutations in this gene are associated with adrenal hyperplasia, pseudohermaphroditism, 17,20 lyase deficiency, and $17 \alpha$-hydroxylase deficiency [41]. The CYP11A1 gene, which encodes a member of the cytochrome P450 family, is a protein located 
in the inner membrane of the mitochondria that catalyses the first step of steroid hormones and converts cholesterol to pregnenolone [42].

\subsection{CYP11A1 Gene}

CYP11A1 gene is a subset of enzymes belonging to the cytochrome P450 superfamily, located on chromosome 15q24.1. The expression of these monooxygenases in the inner membrane of mitochondrial consequently plays a key role in steroid synthesis reactions, cholesterol, and drug metabolism. One of the vital roles is the catalysis of cholesterol to pregnenolone, which is the first and controlling step in synthesising steroid hormones. In addition, two isoforms, A and B, are encoded by two transcripts of variants of this gene [43]. The CYP11A1 gene is expressed in various organs and tissues, including the ovaries, kidneys, breasts, testes, and bladder that cause various disease. Here, we intend to examine the occurrence of polymorphisms in the CYP11A1 gene that increases PCOS risk with infertility. The effect of the CYP11A1 5'UTR sequence stability on the regulation of the gene as a locus for PCOS expansion, particularly in the development of hyperandrogenaemia, was further validated by a case-control study of 20 PCOS families from a British population. Gharani et al. was the first to establish a relationship between PCOS and the CYP11A1 gene. The function of the CYP11A1 gene is critical for the activity of the enzymes involved in androgen metabolism and cholesterol side-chain cleavage. The study discovered a significant correlation between polymorphisms in the pentanucleotide (TTTTA) repeat region of the CYP11A1 5'UTR and a high level of total serum testosterone in PCOS women [44]. The role of CYP11A1 alleles in PCOS with hyperandrogenaemia was also investigated in the Greek population. A total of 170 women, consisting of 80 with PCOS and 90 healthy Greek women with regular menstrual cycles ( $<35$ days), were studied. All the females selected were Caucasian and had registered consecutively over the past three years at the Endocrine Section of the First Department of Medicine, Athens University School of Medicine, Laiko Athens General Hospital. The study searched for alterations in the alleles for CYP11A1 (TTTA)n microsatellite (-528 pairs) in Greek females who complied with PCOS and ethnic controls, and the study showed a strong association between the allele and severity of hyperandrogenaemia in patients with PCOS [45]. Additionally, 100 cases of polycystic ovarian syndrome were evaluated in a study conducted on the population of Indian women. Increased testosterone levels were associated with the presence of six-repeat alleles in the CYP11A1 gene [46]. A polymorphism analysis was carried out by Zhang and colleagues to estimate the association of CYP11A1 SNP rs4077582 with PCOS susceptibility. A potent co-relationship between rs4077582 in CYP11A1 and PCOS susceptibility was observed. In addition, an increase in androgen production by an alteration in the CYP11A1 nucleotide was found, and this effect was confirmed by the alteration of testosterone levels in different genotypes. The study observed that the mRNA's abundance was due to the CYP11A1 promoter's increased activity, which was differentially controlled by the sequences of the 5'UTRs of the mRNA [47]. Likewise, in a similar case study, a population of Egyptian women with polycystic ovary syndrome, 53 patients and 53 controls in the rs4077582, were evaluated, which positively supported the occurrence of polymorphism and its association with PCOS [48]. In some research performed on the CYP11A1 promoter, It has been proposed that the regulation of the CYP11A1 promoter in granulosa cells is controlled by liver receptor homologue-1 (LRH-1) and Steroidogenic element-1 (SF-1) [49]. A 1999 study also supported this hypothesis, and it showed the loss of P450scc due to the knockout SF-1 [50]. Because increases or decreases in the LH hormone have an effect on the downstream responses of steroid hormones in people with various rs4077582 genotypes, the relationship between CYP11A1 and gonadotropins is not clear. In addition, a study conducted on a population of Indian women, among 267 cases diagnosed with polycystic ovary syndrome in comparison to 275 healthy controls, the CYP11A1 polymorphic pentanucleotide repeat was analysed by the PCR-PAGE technique, which showed that the increasing recurrence of polymorphisms could be a biomarker for the risk of PCOS. One of the most important indicators of this study was the study of 
recurrences in both control and patient groups. These copies ranged from a minimum of 2 to a maximum of 16 repetitions, and the examination of demographic data revealed that individuals who showed recurrences of more than 8 had symptoms of ovarian polycystic ovary syndrome. Recurrences of less than eight were obtained in the control group [51]. The results of this study were consistent with the results of a study conducted on Grecian women [45]. This might be assumed that genetic polymorphisms in the CYP11A1 prompter may influence gene expression and may result in a condition related to hormonal changes, such as polycystic ovarian syndrome. Recently, in a case-control study of 128 Iraqi women with PCOS, the incidence of pentanucleotide recurrence was found to be significantly associated with polycystic ovary syndrome. The most significant finding of this study was the prevalence of five and three repeats in the CYP11A1 promoter in Iraqi women, who reported 62 percent and 79.7 percent of the total repeats in CYP11A1, respectively [52], compared to pentanucleotides with nine repeats among the population of Caucasian women in America, six and eight repetitions in Chinese women [53], and four repeats in white women in Spain [54].

In contrast to the research records discussed so far, no significant relationship has been reported in a number of studies that can be cited in Hispanic white women [55], Chinese women [56,57], Argentinian women [58], and Czech women [59]. A recent metaanalysis study reviewed some of the previously reviewed studies, which confirmed a strong association between the occurrence of a recessive trait in individuals and the occurrence of $4 \mathrm{R}$-pentanucleotide recurrences, even as companies of $6 \mathrm{R}-\mathrm{p}$ confirmed the reduced risk of PCOS considering the dominant trait [60]. In addition, another meta-analysis confirmed a strong correlation between polymorphism recurrences in CYP11A1 in the white female population [61], and some studies reported a correlation between these recurrences and an increase or decrease in testosterone levels. In some of these reports, carriers of shorter alleles show higher serum testosterone levels [46]. In other studies, however, there was no association between increased androgen changes in polymorphisms and changes in CYP11A1 transcription [56,62]. In addition, these alleles' variation has a correlation with metabolic traits and obesity [55], a reduction in blood lipids [59], decreased FSH levels [59], and waist to hip ratio, Lower glucose [57] also show a significant correlation incidence with rs11632698 polymorphism, and increased [57] and decreased [47] risk of PCOS in Chinese women rs4077582, and its association with the development of polycystic ovary syndrome and changes in the levels of LH and testosterone [47]. Based on the case history discussed so far (Table 1), CYP11A1 might be considered as a biomarker, which is most likely correlated with infertility in polycystic ovary syndrome.

\subsection{CYP17A1 Gene}

The CYP17A1 gene located on chromosome 10q24.3. It is a subset of enzymes belonging to the cytochrome P450 superfamily. These monooxygenases are expressed in the endoplasmic reticulum and hence play a critical role in steroid production reactions, cholesterol metabolism, and drug metabolism [63]. Enzyme 17-a-hydroxylase/17-20 lyase is encoded by the CYP17A1 gene and converts pregnenolone into 17-hydroxypregnenolone, and 17-hydroxypregnenolone is converted to dehydroepiandrosterone (DHEA) and 4androstenedione via 17,20-lyase activity. The CYP17A1 gene is expressed in various tissues, including the gonads and adrenal cortex, where defects cause various diseases. Here, we study the incidence of polymorphisms in the CYP17A1 gene that causes robust PCOS risk with infertility [64]. One of the significant factor genes in the expansion of PCOS is the CYP17A1 gene. In 2007, B. Echiburú et al. investigated CYP17A1 promoter polymorphisms in the Chilean female population; a total of 159 objects with PCOS manifestation were examined. The study discovered that the rs743572 $\mathrm{T}>\mathrm{C}$ polymorphism in the CYP17A1 gene was one of the variations associated with an increased risk of PCOS. Additionally, clinical and hormonal confirmation was accomplished by the evaluation of insulin tolerance and body weight. A change in the CYP17A1 gene, as well as the presence of the rs743572 T > C polymorphism in this gene, are associated with elevated lipid levels, glucose resistance, 
and weight gain. As a result, polymorphisms in the CYP17A1 gene can be associated with PCOS, along with metabolic pathways [65]. A study was conducted in 2008, and it was performed among 200 Indian women. In this study, the main conclusion is based on data from nucleotide sequencing at the site of CYP17A1 polymorphisms, as well as the study of the hormones including dehydroepiandrosterone DHEAS, 17a-hydroxyprogesterone, androstenedione, and serum testosterone levels to evaluate the 152bp region inside the promoter sequences of CYP17A1 in a distinct combination of women with PCOS manifestations based on the Rotterdam criteria. The promoters of the CYP17A1 gene were evaluated as this region controls the enzymes that regulate the rate-limiting steps in androgen synthesis. The finding of this study revealed an independent association between the polymorphisms of the promoters and the hyperandrogenism found in PCOS patients [46].

In a 2015 case-control study of Iraqi women, two groups of individuals were examined for genetic association between the CYP17A1 allele and the incidence of polycystic ovary syndrome. Out of 123 participants, 84 were confirmed by clinicians with hormonal and clinical manifestations of polycystic ovary syndrome. They were also measured to evaluate the hormones testosterone, prolactin, FSH, and LH. Finally, by the genotypic analysis of individuals, three genotypes were reported, including the most common allele among patients, the C. allele. The TC genotype was the most common allele among controls, and the TT allele was a wild homozygous allele. In addition, as a finding, to the amount of the CC genotype in the population of women with polycystic ovary syndrome and its absence in healthy individuals, the importance of -34 (T/C) polymorphism might be considered as a marker to identify the disease [66]. In the same population, another study was conducted in 2014 by Marwa B. M et al.; on the Iraqi women population: 2 groups of 61 women with polycystic ovary syndrome and 30 in the control group were analysed for genotype analysis of the effect of polymorphism and its relationship with the disease. Between the control and patient groups, there were significant differences in the FSH and HDL levels; however, there were no significant differences in the cholesterol, triglyceride, VDL, or LDL levels. In addition to genotyping, TC was reported as the mutant allele and TT as the wild allele; nevertheless, the genotyping investigation did not reveal a relationship between polycystic ovarian syndrome and the CYP17A1 polymorphism [67].

In another study conducted in 2018 on 250 cases of polycystic ovary syndrome and 250 cases in the North Indian female population as a control, the rs743572 allele was analysed in CYP17A1. For the biochemical evaluation of patients, the hormones HDL, triglyceride, and cholesterol were analysed in both groups of patients and the control group. The results of the polymorphism study at $-34 \mathrm{~T} / \mathrm{C}$ in CYP17A1 revealed a significant difference in the group of women with polycystic ovary syndrome compared to the control group and similarly confirmed the association of the rs743572 allele in women in northern India with PCOS [68] with a study conducted in the Greek population [69]. In 2017, the case-control study by Z. Rahimi and E. Mohammadi was performed among the women population of western Iran. One hundred and nine individuals were enrolled as controls against fifty women with PCOS after clinical examinations and confirmed by a gynaecologist. The aim of this research was to investigate the polymorphism in -34 T/C in CYP17A1. In addition, for clinical evaluation of patients, measurements of various hormone levels were taken, including sex hormone-binding globules, dehydroepiandrosterone (DHEA) and oestradiol. The results of the essays revealed that the levels of SHBG and oestradiol in the group of patients with polycystic ovary syndrome were lower than the control group. In contrast, the level of DHEA in patients was higher than in the control group. In addition, a positive association was reported between the incidence of symptoms of polycystic ovary syndrome in patients and carriers of polymorphism in $-34 \mathrm{~T} / \mathrm{C}$ [70]. In a recent study of the Pakistani female population in 2020, 234 women with polycystic ovary syndrome with two phenotypes of three prototypes based on ASRM consensus were among the 344 participants in the project. In this study, the SNP rs743572 was amplified in CYP17A1 by the PCR-RFLP method. The findings of this study demonstrated unequivocally that the frequency distribution of the TC genotype is greater in patients with PCOS than in controls. In Pakistani 
women, there was a substantial correlation between the risk of infertility in polycystic ovary syndrome and the occurrence of the CYP17A1 polymorphism [71]. Another case study was conducted by S. Ashraf et al. on the Kashmir women population in India in 2020. The aim of this study was to investigate the relationship between hyperandrogenism and PCOS; for this purpose, they examined the number of $\mathrm{t} 394$ patients with PCOS against 306 control samples. To evaluate the relationship between CYP17A1 and their hyperandrogenism, they measured hormonal and biochemical tests and anthropometer measurements between the case and control groups. In addition, in order to analyse the genotype, PCR-RFLP was applied. The results of their study showed that between the distribution of alleles, there was no significant difference in genotype between case and control individuals, while there is a significant relationship between increased testosterone levels and clinical phenotypes such as alopecia between patients and healthy individuals [72]. In 2018, L. Wang studied 17 subfamilies in the Chinese female population, in which he found a link between polycystic ovary syndrome and insulin resistance and blood pressure. The purpose of this case-control study, which included 1,860 individuals from the control and case groups, was to determine the impact of $C Y P 17 A 1$ polymorphism on the control and patient groups. Their research established a strong association between the rs2413409, rs17115149, and rs10044677 alleles with the occurrence of type 2 diabetes mellitus. The conclusion of their study established an association between the rs17115149 allele and the case group [73]. Contrary to the results stated above, a number of studies also have differences in results and found no association between the presence of polymorphisms in the CYP17A1-34T/C allele and hyperandrogenism in PCOS patients, such as in the study of Thai women population in 2015 by Ka. Techatraisak [74], in Turkey [75], and Caucasians in America [76]. A large number of polymorphism studies in different ethnicities and in different parts of the world have analysed the relationship between CYP17A1 and PCOS [77]. The description and identification of polymorphisms in CYP17A1 three-nucleotide variants was investigated for the first time by Crocitto et al. [78]. A report of the transition between a base pair of cytosine to adenine at nucleotide 5144 in the CYP17A1 gene was made by Miyoshi et al. [79]. There are studies in which a significant association between SNP - 34T/C in CYP17A1 and PCOS has been reported, which has been confirmed by researchers in various ethnicities, including Indians [68], Grecians [69], and Koreans [80]. Allele -34 in CYP17A1 has also been reported as a valuable biomarker in assessing breast cancer in females [81] and in males [82,83]. In addition, it is probably associated as a biomarker associated with prostate cancer in men [84]. Even though these studies may seem to suggest that CYP17A1 is not directly the susceptibility gene that causes infertility, the abnormal activity of the gene may have an effect on the sequential reactions of the steroidogenesis pathways in which, together with other defective genes in the pathway, may contribute to infertility in PCOS women. Table 2 describes the types of genetic variants associated with infertility in women with polycystic ovary syndrome as mentioned earlier.

\subsection{CYP19A1 Gene}

One of the crucial enzymes in oestrogen synthesis is aromatase, an enzyme encoded by the cytochrome P450 family 19 subfamilies A member one, CYP19A1 gene. The gene is located on the short arm of chromosome 15 (15q21.2) and is expressed in some of the vital organs, including ovaries, testicular, adipose, bone, placental, and cerebrum tissues. In females, aromatase is most active in the ovaries. Mutations of the CYP19A1 gene have been associated with various aromatase deficiency characterized by a low oestrogen level and a high level of androgen [86]. The activity of the gene is controlled by nine consecutive exons positioned in the long $93 \mathrm{~kb}$ gene regulative factor. In the ovary, the aromatase enzyme production is organized by a portion of the promoter located $1 \mathrm{~kb}$ pair upstream of exon two of the gene [87]. Irregular activation of the promoter could cause oestrogen-stimulating disorders, including breast cancer and endometriosis. Here, we aim to investigate the incident of polymorphisms in the CYP19A1 gene that increases PCOS risk with infertility. A high number of polymorphisms of $7<n<13$ repeats in intron number 
4 has been associated with a high level of aromatase concentration. An aggregation of incomplete development of follicles explains PCOS because of the decreasing densities of positional oestrogen and aromatase performance [88]. The alteration of 10 or 12 repeats in the genetics' allele has been proposed as a potential breast cancer allele associated with hyperactive aromatase enzyme activity. Women with PCOS, on the other hand, had shorter CYP19A1 alleles with more than nine (TTTA) $n$ repeats. Notably, these individuals with PCOS had the greatest blood testosterone and testosterone/oestradiol ratios during the early follicular phase of the menstrual cycle [89]. Studies on the CYP19A1 gene also identified its different variants associated with the risk of developing reproductive cancers in women. Hence, further investigation of the CYP19A1 gene polymorphisms may be the subject of further research. Alterations in the CYP19A1 gene polymorphisms may affect the aromatase enzyme activity by acting on it; therefore, the results obtained in these changes and their effects on folliculogenesis regulation and induction of ovulation can be used in the treatment of infertility. Additionally, the results of polymorphism studies may aid in predicting the likelihood of a favourable response to in vitro fertilisation (IVF) infertility therapy. As a result, miscarriage risk is decreased, and fertility is likely to rise [90]. These findings are in line with those found in the literature, which, in 2010, Lee et al. screened for CYP19A1 SNPs among Koreans. The CYP19A1 gene was directly sequenced from 50 normal cases. A sum of 19 variations was identified: 4 in exons, 10 in introns, 6 in the $5^{\prime}$-untranslated regions (UTR), and 1 in $3^{\prime}$-UTR. The distribution of CYP19A1 (TTTA)n polymorphisms found was such that the most frequent allele was (TTTA)7 (66 percent), followed by (TTTA)11 (30 percent), (TTTA)12 (3 percent), and (TTTA)13 (1 percent). They resequenced the CYP19A1 gene for the first time in a Korean population and discovered that these variants have an essential function in the oestrogen pathway [91].

Many studies have revealed that such alterations in the oestrogen production rate may lead to the prospect of oestrogen-related diseases, such as breast, endometrial, and prostate cancers. Moreover, cancer studies have revealed that CYP19A1 also plays a role in obesity and infertility in Chinese women [92]. A case-control study was undertaken in 2014 on 225 normal Chinese women and 146 patients with endometriosis-related infertility, as proven by pathological and laparoscopic criteria. On the other hand, they discovered that the AA genotype of the CYP19A1 polymorphism was strongly associated with an increased risk of endometriosis and infertility in the population [93]. In a case-control study conducted in 2011 on 600 Greek women, the case group was treated with gonadotropin stimuli. The aim of this study was to investigate the presence of polymorphism (TTTA)n in CYP19A1 and its effect on treatment outcome. The results showed that there was a positive relationship between recurrences of (TTTA) $n$ polymorphism and FSH hormone levels and the number and size of follicles in the subjects [94]. In another study conducted in another ethnicity in China. X. Zhang et al. examined 661 people, and the aim was to investigate the relationship between rs 2470152 polymorphism and aromatase activity in the Chinese female population. The results of genotype studies revealed that the presence of rs2470152 polymorphism was not directly related to PCOS occurrence. However, in individuals with the TC genotype, the risk of hyperandrogenism and PCOS may increase due to the inhibition of aromatase enzyme activity [95]. Another study conducted in 2012 by L. Lazaros et al. examined the effect of the CYP19A1 variant on infertility treatment in patients with the polycystic ovarian syndrome; in this study, in which 322 Greek women participated, a significant association between the occurrence of 7 repeats in (TTTA)n, CYP19A1 polymorphism, and its effect on gonadotropin treatment was proven [96], This effect is most likely explained by a change in the ratio of androgen to oestrogen; nevertheless, these findings contradict those published by P. Xu et al. in 2013 among 522 cases and controls. The purpose of this study was to determine the link between the (TTTA) $n$ allele polymorphism in CYP19A1 and the risk of developing PCOS. In this research, fluorescent DNA fragments obtained from PCR confirmed the outcomes of testing different repeats, including 7, 8, 10,11, and 16 repeats, and no significant relationship was observed between the incidence of the allele (TTTA) $n$ in the Chinese female [97]. At the same time, another 
study was performed on Chinese women, and in this population, including 293 females, the aim was to evaluate the effect of rs700519, rs700518, and rs727479 alleles in patients treated with the ART method among PCOS patients. The results show that the CGT and CAT haplotypes were desirable to a fertility result in PCOS patients [98].

Another polymorphism study was performed in Iranian women and 140 people in this case-control study to ascertain a link between rs2414096 CYP19A1 and polycystic ovary syndrome; outcomes revealed that the rs2414096 variant was significantly involved in the probability of individuals developing PCOS [99]. In 2018, a case and control study was conducted by R. Kaur et al. where 500 women from the North Indian population were analysed, and two alleles, rs2414096 and rs700519, were examined among the two groups of control cases. In addition, the PCR-RFLP method was employed to examine the genotype of individuals. The study results did not show a significant association in the study groups [68]. The studies of these alleles in different ethnicities in other countries have confirmed the entity of a relationship that indicates the impact of ethnicity and geography studied. China [100] was shown to be significantly associated with the age of menarche in Han Chinese women, FSH levels, with increased oestradiol to testosterone ratios (E2/T), and finally, increased risk of PCOS development. This argument is consistent with the findings of $n$. Xita in Greece [101].

The hormonal imbalance caused by anovulation and subsequent infertility in patients with polycystic ovary syndrome is associated with a loss of oestrogen production inhibition, and there is a significant association between increased oestrogen levels and the development of hyperplasia and, subsequently, an increased risk of endometrial cancer in women with PCOS [102]. Endometrial cancer is one of the oncoming cancers in developed countries and is also the fourth most common cancer in the world [103]. The most important risk factors for this cancer include polycystic ovary syndrome, diabetes, and obesity [104]. Conceptually similar work has also been carried out by A. Ayyob et al. on the Iraqi women population. Significant correlation was reported between the presence of polymorphisms in CYP19A1 and endometrial cancer. In this study, which was performed employing 122 Iraqi women, a remarkable association was reported between the presence of alleles with longer $(n \geq 9)$ repetitions and the risk of endometrial and ovarian cancer. Repetitions of (TTTA)n 12, (TTTA)n 11, and (TTTA) $n 9$ were reported to be OR 1.56, 2.16, and 1.56, respectively, with the probability of doubling cancers' risk [105]. This evidence is supported by the results of a systematic review conducted in 2016 [106]. The authors believe that the increased risk of endometrial cancer might be correlated with the increased prevalence of infertility in the population of women with polycystic ovary syndrome. Another pilot study was conducted among the Indian female population between 2018 and 2019, and the rs2470152 polymorphism was considered in CYP19A1. In this study, which employed 300 individuals, the results confirmed a correlation between the incidence of rs 2470152 polymorphism and the risk of developing polycystic ovary syndrome [107]. These results are confirmed by evidence obtained by M. Rowaa et al. In this study, they examined the association of polymorphism in rs2414096 and the possibility of hyperandrogenism in the Egyptian female population. The results confirmed an increase in the ratio of LH to FSH in women with polycystic ovary syndrome. In addition, a significant relationship was reported between the incidence of rs2414096 polymorphism and the possibility of PCOS [108]. The implications of our findings might suggest that CYP19A1 is probably the susceptible gene that contributes to infertility. Still, the abnormal transcripts may affect the sequential reactions of the steroidogenesis pathways which, together with other defective genes in the pathway, may contribute to infertility in PCOS women. Table 3 describes the types of CYP19A1 genetic variants associated with infertility in women with polycystic ovary syndrome. 
Table 1. Correlation between CYP11A1 genetic variants and PCOS with infertility.

\begin{tabular}{|c|c|c|c|c|c|c|c|c|c|c|}
\hline Gene Name & $\begin{array}{l}\text { SNP/STR } \\
\text { Allele }\end{array}$ & Study Design & Country & Ethnicity & $\begin{array}{c}\text { SS; } \\
\text { Case/Control }\end{array}$ & $\begin{array}{l}\text { Genotype } \\
\text { Methods }\end{array}$ & $\begin{array}{l}\text { Diagnostic } \\
\text { Criteria }\end{array}$ & $\begin{array}{c}\text { Clinical } \\
\text { Characteristics }\end{array}$ & Risk Association & Ref \\
\hline CYP11A1 & $\begin{array}{c}(\text { TTTTA)n } \\
n=4^{*}, 6,8,9\end{array}$ & $\begin{array}{l}\text { Case-control } \\
\text { study }\end{array}$ & Greece & Greek & $80 / 90$ & PCR & NIH/NICHD & Hyperandrogenism & $\begin{array}{l}\text { The pentanucleotides allele with } \\
4 \text { repeats }(n=4) \text { is associated with } \\
\text { higher serum total testosterone } \\
\text { levels in PCOS. }\end{array}$ & [45] \\
\hline CYP11A1 & $\begin{array}{l}(\text { TTTTA }) \\
n=4,6 * 8,9 \\
\quad 10,12\end{array}$ & $\begin{array}{l}\text { Case-control } \\
\text { study }\end{array}$ & India & Asian & $100 / 100$ & PCR & Rotterdam & Hyperandrogenism & $\begin{array}{l}\text { A significant association of the } \\
\text { pentanucleotides allele with } \\
6 \text { repeats }(n=6) \\
\text { with total testosterone levels is } \\
\text { observed in PCOS group. }\end{array}$ & [46] \\
\hline CYP11A1 & rs4077582 & $\begin{array}{l}\text { Case-control } \\
\text { study }\end{array}$ & Egypt & Egyptians & $53 / 53$ & PCR-RFLP & Rotterdam & $\begin{array}{l}\text { Diabetes mellitus, } \\
\text { hirsutism, hyper- } \\
\text { androgenism }\end{array}$ & $\begin{array}{l}\text { The incidence of this } \\
\text { polymorphism was positively } \\
\text { associated with PCOS. }\end{array}$ & [48] \\
\hline CYP11A1 & $\begin{array}{c}(\text { TTTTA) } n \\
n=2-16,8 *\end{array}$ & $\begin{array}{l}\text { Case-control } \\
\text { study }\end{array}$ & India & Asian & $267 / 275$ & PCR-PAGE & Rotterdam & Hyperandrogenism & $\begin{array}{l}\text { There was a significant increase in } \\
\text { the pentanucleotides allele with } \\
8 \text { repeats }(n=8) \text { with higher } \\
\text { testosterone levels in PCOS. }\end{array}$ & [51] \\
\hline CYP11A1 & $\begin{array}{c}(\text { AAAAT) } n \\
n=3,5^{*}, 6,7,8\end{array}$ & $\begin{array}{l}\text { Case-control } \\
\text { study }\end{array}$ & Iraq & Asian & $74 / 58$ & $\mathrm{PCR} /$ sequencing & Rotterdam & $\begin{array}{l}\text { Polycystic ovaries } \\
\text { oligovulation, hy- } \\
\text { perandrogenism }\end{array}$ & $\begin{array}{l}\text { There was a significant } \\
\text { relationship between the } \\
\text { pentanucleotides allele with } \\
5 \text { repeats }(n=5) \text { and PCOS. }\end{array}$ & [52] \\
\hline CYP11A1 & $\begin{array}{c}(\text { TTTTA }) n \\
n=4,6,8,9\end{array}$ & $\begin{array}{l}\text { Case-control } \\
\text { study }\end{array}$ & Spain & Caucasian & $92 / 33$ & $\begin{array}{c}\text { PCR/ } \\
\text { sequencing }\end{array}$ & NIH/NICHD & $\begin{array}{l}\text { Hyperandrogenism } \\
\text { Hirsutism }\end{array}$ & $\begin{array}{l}\text { No association was found between } \\
\text { (TTTTA)n in CYP11A1 and } \\
\text { hyperandrogenism. }\end{array}$ & [55] \\
\hline CYP11A1 & $\begin{array}{c}(\text { TTTTA) } n \\
n=4,6,8,9\end{array}$ & $\begin{array}{l}\text { Case-control } \\
\text { study }\end{array}$ & China & Asian & $96 / 78$ & PCR & Rotterdam & Hyperandrogenism & $\begin{array}{l}\text { No association was found between } \\
\text { (TTTTA)n in CYP11A1 and } \\
\text { hyperandrogenism. }\end{array}$ & [56] \\
\hline CYP11A1 & $\begin{array}{l}(\text { TTTTA)n } \\
n=4,8\end{array}$ & $\begin{array}{l}\text { Case-control } \\
\text { study }\end{array}$ & China & Asian & $125 / 121$ & PCR & Rotterdam & $\begin{array}{l}\text { Anovulation \& } \\
\text { Hyperandro- } \\
\text { genism }\end{array}$ & $\begin{array}{l}\text { There is no statistically } \\
\text { significant difference. }\end{array}$ & [57] \\
\hline CYP11A1 & $\begin{array}{l}(\text { TTTTA }) n \\
n=4,6,8\end{array}$ & $\begin{array}{l}\text { Case-control } \\
\text { study }\end{array}$ & Argentine & Non-Caucasian & $65 / 58$ & PCR & $\mathrm{NIH} / \mathrm{NICHD}$ & Hyperandrogenism & $\begin{array}{l}\text { No statistically significant } \\
\text { relationship was found between } \\
\text { the pathogenesis of CYP11A1 } \\
\text { and PCOS. }\end{array}$ & [58] \\
\hline CYP11A1 & $\begin{array}{c}(\text { TTTTA }) n \\
n=4\end{array}$ & $\begin{array}{l}\text { Case-control } \\
\text { study }\end{array}$ & Czech & Caucasian & $256 / 109$ & PCR & Rotterdam & Hyperandrogenism & $\begin{array}{l}\text { There is no statistically significant } \\
\text { difference. }\end{array}$ & [59] \\
\hline
\end{tabular}

$n$ : Number of Repeats; NIH/NICHD: National Institutes of Health/National Institute of Child Health and Human Development; Rotterdam: Rotterdam PCOS Consensus, ${ }^{*}$ Risk alleles which is associated with clinical manifestation(s) of PCOS; SS: Sample Size. 
Table 2. Correlation between CYP17A1 genetic variants and PCOS with infertility.

\begin{tabular}{|c|c|c|c|c|c|c|c|c|c|c|}
\hline Gene Name & $\begin{array}{l}\text { SNP/STR } \\
\text { Allele }\end{array}$ & Study Design & Country & Ethnicity & $\begin{array}{c}\text { SS; } \\
\text { Case/Control } \\
\end{array}$ & $\begin{array}{l}\text { Genotype- } \\
\text { Methods }\end{array}$ & $\begin{array}{c}\text { Diagnostic } \\
\text { Criteria }\end{array}$ & $\begin{array}{c}\text { Clinical } \\
\text { Characteristics } \\
\end{array}$ & Risk Association & Ref \\
\hline CYP17A1 & rs743572 & $\begin{array}{l}\text { Case-control } \\
\text { study }\end{array}$ & Chile & Caucasian & $66 / 93$ & PCR -RFLP & NIH/NICHD & $\begin{array}{l}\text { hormonal and } \\
\text { clinical evidence } \\
\text { of PCOS }\end{array}$ & $\begin{array}{l}\text { CYP17A1 is associated with } \\
\text { metabolic pathway and obesity in } \\
\text { women with PCOS }\end{array}$ & [65] \\
\hline CYP17A1 & rs743572 & $\begin{array}{l}\text { Case-control } \\
\text { study }\end{array}$ & Iraq & Asian & $84 / 65$ & PCR & - & Anovulation & Positive correlation & [85] \\
\hline CYP17A1 & rs743572 & $\begin{array}{l}\text { Case-control } \\
\text { study }\end{array}$ & Iraq & Asian & $61 / 30$ & PCR-RFLP & Rotterdam & PCOS criteria & $\begin{array}{l}\text { There is a correlation between the } \\
-34 \mathrm{~T}>\mathrm{C} \text { allele and } \\
\text { increasing HDL }\end{array}$ & [67] \\
\hline CYP17A1 & rs743572 & $\begin{array}{l}\text { Case-control } \\
\text { study }\end{array}$ & India & Asian & $250 / 250$ & PCR-RFLP & Rotterdam & Anovulation & $\begin{array}{c}\text { CYP17A1 34 T > C occurrence had } \\
\text { a significant relation with PCOS } \\
\text { patients }\end{array}$ & [68] \\
\hline CYP17A1 & rs743572 & $\begin{array}{l}\text { Case-control } \\
\text { study }\end{array}$ & Iran & Asian & $50 / 109$ & PCR-RFLP & Rotterdam & PCOS criteria & $\begin{array}{l}\text { Polymorphism in CYP17A1 is } \\
\text { associated with the risk of PCOS }\end{array}$ & [70] \\
\hline CYP17A1 & rs743572 & $\begin{array}{l}\text { Case-control } \\
\text { study }\end{array}$ & Pakistan & Asian & $204 / 100$ & PCR-RFLP & Rotterdam & PCOS criteria & $\begin{array}{l}\text { rs743572 is correlated with the } \\
\text { occurrence of PCOS }\end{array}$ & [71] \\
\hline CYP17A1 & rs743572 & $\begin{array}{l}\text { Case-control } \\
\text { study }\end{array}$ & India & Asian & $394 / 306$ & PCR-RFLP & Rotterdam & Hyperandrogenism & $\begin{array}{l}\text { Confirmation of the role of SNP in } \\
\text { hyperandrogenism with increasing } \\
\text { androgen }\end{array}$ & [72] \\
\hline CYP17A1 & rs743572 & $\begin{array}{l}\text { Cross-sectional } \\
\text { study }\end{array}$ & Thailand & Asian & 210 & PCR-RFLP & Rotterdam & PCOS criteria & $\begin{array}{l}\text { There was no significant } \\
\text { association between }-34 \mathrm{~T}>\mathrm{C} \text { and } \\
\text { insulin resistance }\end{array}$ & [74] \\
\hline CYP17A1 & rs743572 & $\begin{array}{l}\text { Case-control } \\
\text { study }\end{array}$ & Turkey & Asian & $44 / 50$ & PCR-RFLP & Rotterdam & PCOS criteria & $\begin{array}{l}\text { There was no association among } \\
\text { case and control groups in allele } \\
\qquad-34 \mathrm{~T}>\mathrm{C}\end{array}$ & [75] \\
\hline CYP17A1 & rs743572 & $\begin{array}{l}\text { Case-control } \\
\text { study }\end{array}$ & America & Caucasian & $259 / 161$ & PCR & NIH/NICHD & PCOS criteria & $\begin{array}{l}\text { There was no association with the } \\
\text { development of PCOS and } \\
\text { CYP17A1 C/T }\end{array}$ & [76] \\
\hline
\end{tabular}

NIH/NICHD: National Institutes of Health/National Institute of Child Health and Human Development; Rotterdam: Rotterdam PCOS Consensus SS: Sample Size. 
Table 3. Correlation between CYP19A1 genetic variants and PCOS with infertility.

\begin{tabular}{|c|c|c|c|c|c|c|c|c|c|c|}
\hline Gene Name & $\begin{array}{l}\text { SNP/STR } \\
\text { Allele }\end{array}$ & Study Design & Country & Ethnicity & $\begin{array}{c}\text { SS; } \\
\text { Case/Control }\end{array}$ & $\begin{array}{l}\text { Genotype } \\
\text { Methods }\end{array}$ & $\begin{array}{c}\text { Diagnostic } \\
\text { Criteria }\end{array}$ & $\begin{array}{c}\text { Clinical } \\
\text { Characteristics }\end{array}$ & Risk Association & Ref \\
\hline CYP19A1 & $\begin{array}{c}(\text { TTTA }) n \\
n=7^{*}-12\end{array}$ & $\begin{array}{l}\text { Case-control } \\
\text { study }\end{array}$ & Greece & Greek & $300 / 300$ & PCR-PAGE & - & $\begin{array}{c}\text { Male } \\
\text { factor-infertility }\end{array}$ & $\begin{array}{c}\text { There was a significant association } \\
\text { between the tetranucleotide allele } \\
\text { with } 7 \text { repeats }(n=7) \text { and } \\
\text { FSH level. }\end{array}$ & [94] \\
\hline CYP19A1 & rs2470152 & $\begin{array}{l}\text { Case-control } \\
\text { study }\end{array}$ & China & Asian & $364 / 297$ & PCR- RFLP & Rotterdam & PCOS features & $\begin{array}{l}\text { rs2470152 polymorphism was } \\
\text { associated with aromatase activity }\end{array}$ & [95] \\
\hline CYP19A1 & $\begin{array}{c}(\text { TTTA }) n \\
n=7^{*}-12\end{array}$ & $\begin{array}{l}\text { Case-control } \\
\text { study }\end{array}$ & Greece & Greek & $132 / 200$ & PCR-PAGE & NIH/NICHD & $\begin{array}{l}\text { Ovulatory- } \\
\text { dysfunction }\end{array}$ & $\begin{array}{l}\text { Carriers with the tetranucleotide } \\
\text { allele with } 7 \text { repeats }(n=7) \\
\text { presented higher testosterone } \\
\text { levels compared to non-carriers } \\
\text { with the tetranucleotide allele with } \\
7 \text { repeats }(n=7)\end{array}$ & [96] \\
\hline CYP19A1 & $\begin{array}{c}(T T T A) n \\
n=7,8,10,11 \\
12,13\end{array}$ & $\begin{array}{l}\text { Case-control } \\
\text { study }\end{array}$ & China & Asian & $222 / 281$ & $\begin{array}{l}\text { PCR-Capillary } \\
\text { electrophoresis }\end{array}$ & Rotterdam & PCOS features & $\begin{array}{l}\text { PCOS patients showed a higher } \\
\text { frequency of short alleles } \\
\text { compared to controls. }\end{array}$ & [97] \\
\hline CYP19A1 & $\begin{array}{l}\text { rs727479 } \\
\text { rs700518 } \\
\text { rs700519 }\end{array}$ & $\begin{array}{l}\text { Case-control } \\
\text { study }\end{array}$ & China & Asian & $150 / 143$ & PCR-DHPLC & Rotterdam & PCOS features & $\begin{array}{l}\text { The CGT and CAT haplotypes } \\
\text { were desirable to fertility result in } \\
\text { PCOS patients }\end{array}$ & [98] \\
\hline CYP19A1 & rs2414096 & $\begin{array}{l}\text { Case-control } \\
\text { study }\end{array}$ & Iran & Asian & $70 / 70$ & PCR-RFLP & Rotterdam & PCOS features & $\begin{array}{c}\text { There was a positive relation } \\
\text { between rs2414096 alleles in } \\
\text { PCOS group }\end{array}$ & [99] \\
\hline CYP19A1 & rs2470152 & $\begin{array}{l}\text { Case-control } \\
\text { study }\end{array}$ & India & Asian & $120 / 180$ & PCR-RFLP & Rotterdam & PCOS feature & $\begin{array}{l}\text { Allele rs } 2470152 \text { was significantly } \\
\text { higher in women with PCOS }\end{array}$ & [107] \\
\hline CYP19A1 & rs2236722 & $\begin{array}{l}\text { Case-control } \\
\text { study }\end{array}$ & Iran & Asian & $50 / 109$ & PCR & Rotterdam & $\begin{array}{c}\text { Ovarian } \\
\text { dysfunction }\end{array}$ & $\begin{array}{c}\text { Incidence of rs } 2236722 \\
\text { polymorphism may not be } \\
\text { associated with an increased risk } \\
\text { of PCOS }\end{array}$ & [70] \\
\hline CYP19A1 & rs2414096 & $\begin{array}{l}\text { Case-control } \\
\text { study }\end{array}$ & Egypt & Egyptians & $30 / 30$ & PCR-RFLP & Rotterdam & PCOS criteria & $\begin{array}{l}\text { Allele rs2414096 was associated } \\
\text { with aromatase deficiency and } \\
\text { hyperandrogenism }\end{array}$ & [109] \\
\hline CYP19A1 & rs2414096 & $\begin{array}{l}\text { Case-control } \\
\text { study }\end{array}$ & Iraq & Asian & $84 / 65$ & PCR-RFLP & Rotterdam & Oligomenorrhea & $\begin{array}{l}\text { Allele rs2414096 present was } \\
\text { related to hyperandrogenism in } \\
\text { case group }\end{array}$ & [66] \\
\hline
\end{tabular}

DHPLC: Denaturing high-performance liquid chromatography; $n$ : Number of Repeats; NIH/NICHD: National Institutes of Health/National Institute of Child Health and Human Development; Rotterdam: Rotterdam PCOS Consensus; ${ }^{*}$ Risk alleles which is associated with clinical manifestation(s) of PCOS; SS: Sample Size. 


\section{Concluding Remarks}

Females worldwide are affected by polycystic ovary syndrome, a multifactorial endocrine condition that affects several systems, leading to infertility and anovulation [109]. Women with PCOS are more likely to develop type 2 diabetes mellitus (T2DM) as a result of the metabolic syndromes and cardiovascular complications associated with PCOS. In the majority of studies, changes in steroidogenesis pathways, notably in hormone synthesis and control, have been linked to the prevalence of PCOS. Women's menstrual cycles are regulated by the natural functions of hormones. As a result, PCOS women may experience infertility as a result of interrupting these fertility cycle processes. It is possible that ovarian cysts are caused by long-term irregularities in women's hormone levels. On the other hand, women with PCOS are more likely to have elevated levels of androgen, a masculine hormone [110].

Because of its multifactorial nature, both genetic and environmental factors are involved. Accordingly, identifying the susceptibility genetic variations that are key factors in modulating the production of steroids may give crucial insights into the development of new therapeutic options for PCOS and infertility concerns in women. Because each individual's SNP profile is unique, more investigations in various populations are required to resolve the controversy surrounding the effect of CYP11A1, CYP17A1, and CYP19A1 polymorphisms on infertility and PCOS. Although some of the CYP genes we were reviewing in this research have not been repeatedly associated with PCOS and infertility clinical manifestations, some of them have been repeatedly associated with previously mentioned disease symptoms in different populations: (1) CYP17A1: rs743572 in Chile [65], India [46,58,72], Iraq [67], Iran [70], and Pakistan [71]; (2) CYP19A1: tetranucleotide allele with 7 repeats (TTTA)7 in Greece [94,96], rs2470152 in China [95], and India [107], and rs2414096 in Iran [99], Egypt [109], and Iraq [66]. In summary, however, most research only covers a small portion of the subject of genetic variations. As a consequence, it is envisaged that future developments will result in a better understanding of the role of CYP genetic variations in the aetiology of PCOS with infertility.

Author Contributions: R.H.: project management, conceptualization, review and editing; M.P.: first draft preparation, formal analysis, review and editing; R.A.: data curation, writing-review and editing; M.B.O.: methodology, validation; M.S.: visualization, conceptualization; N.N.: investigation, review and editing, data curation; H.A.H.: supervision, conceptualization, data curation, formal analysis. All authors have read and agreed to the published version of the manuscript.

Funding: The authors have stated that no grant has been spent.

Institutional Review Board Statement: This article does not contain any studies with human participants or animals performed by any of the authors.

Informed Consent Statement: No individual information was used in this study.

Data Availability Statement: All the analysed information has been published in this article.

Conflicts of Interest: The authors declare that they have no competing interests. The authors have stated that their interests do not conflict with each other.

$\begin{array}{ll}\text { Abbreviations } \\ \text { ADIPOQ } & \text { Adiponectin } \\ \text { ARI } & \text { Aldehyde reductase 1 } \\ \text { AMH } & \text { Anti-Mullerian hormone } \\ \text { AIs } & \text { Aromatase inhibitors } \\ \text { CYP21 } & \text { 21-hydroxylase gene } \\ \text { CYP11A } & \text { Cholesterol side-chain cleavage enzyme } \\ \text { CYP19A1 } & \text { Cytochrome P450 family 19 subfamilies A member 1 } \\ \text { CYPs } & \text { Cytochrome P450 enzymes }\end{array}$




$\begin{array}{ll}\text { CNS } & \text { Central nervous systems } \\ \text { DHEA } & \text { Dehydroepiandrosterone } \\ \text { FSH } & \text { Follicle-stimulating hormone } \\ \text { GWAS } & \text { Genome-wide association study } \\ \text { HA } & \text { Hyperandrogenism } \\ \text { HCG } & \text { Human choriogonadotropin } \\ \text { HSDs } & \text { Hydroxysteroid dehydrogenases } \\ \text { INSR } & \text { Insulin receptor } \\ \text { INS } & \text { Insulin } \\ \text { IRS-1 } & \text { Insulin receptor substrate 1 } \\ \text { IVF } & \text { In vitro fertilization } \\ \text { LHCGR } & \text { Luteinizing hormone/Choriogonadotropin receptor } \\ \text { LH } & \text { luteinizing hormone } \\ \text { MMP } & \text { Matrix metalloproteinase } \\ \text { PCOS } & \text { Polycystic ovary syndrome } \\ \text { SNPs } & \text { Single nucleotide polymorphisms } \\ \text { StAR } & \text { Steroidogenic acute regulatory protein } \\ \text { T2DM } & \text { Type } 2 \text { diabetes mellitus } \\ \text { UTR } & \text { Untranslated region } \\ \text { SHBG } & \text { Sex hormone-binding globulin }\end{array}$

\section{References}

1. Visser, J.A. The importance of metabolic dysfunction in polycystic ovary syndrome. Nat. Rev. Endocrinol. 2021, 17, 77-78. [CrossRef] [PubMed]

2. Hong, X.; Qin, P.; Yin, J.; Shi, Y.; Xuan, Y.; Chen, Z.; Zhou, X.; Yu, H.; Peng, D.; Wang, B. Clinical manifestations of polycystic ovary syndrome and associations with the vaginal microbiome: A cross-sectional based exploratory study. Front. Endocrinol. 2021, 12, 662725. [CrossRef] [PubMed]

3. Chang, S.; Dunaif, A. Diagnosis of polycystic ovary syndrome. Endocrinol. Metab. Clin. N. Am. 2021, 50, 11-23. [CrossRef] [PubMed]

4. Gambineri, A.; Cecchetti, C.; Altieri, P.; Ribichini, D.; Lo Preiato, V.; Fanelli, F.; Pagotto, U. Secondary PCOS: Well-defined causes, leading to the PCOS phenotype. In Polycystic Ovary Syndrome; Elsevier: Amsterdam, The Netherlands, 2022; pp. 15-22. [CrossRef]

5. Geraghty, P. The Interaction of Menopause and Chronic Disease. In Each Woman's Menopause An Evidence Based Resource; Springer: Berlin/Heidelberg, Germany, 2022; pp. 91-120. [CrossRef]

6. Walker, K.; Decherney, A.H.; Saunders, R. Menstrual dysfunction in PCOS. Clin. Obstet. Gynecol. 2021, 64, 119-125. [CrossRef]

7. Tehrani, F.R.; Behboudi-Gandevani, S.; Yarandi, R.B.; Naz, M.S.G.; Carmina, E. Prevalence of acne vulgaris among women with polycystic ovary syndrome: A systemic review and meta-analysis. Gynecol. Endocrinol. 2021, 37, 392-405. [CrossRef]

8. Almeshari, W.K.; Alsubaie, A.K.; Alanazi, R.I.; Almalki, Y.A.; Masud, N.; Mahmoud, S.H. Depressive and anxiety symptom assessment in adults with polycystic ovarian syndrome. Depression Res. Treat. 2021, 2021, 6652133. [CrossRef]

9. Pundir, C.S.; Deswal, R.; Narwal, V.; Dang, A. The prevalence of polycystic ovary syndrome: A brief systematic review. J. Hum. Reprod. Sci. 2020, 13, 261-271. [CrossRef]

10. Guo, F.; Huang, Y.; Fernando, T.; Shi, Y. Altered Molecular Pathways and Biomarkers of Endometrial Receptivity in Infertile Women with Polycystic Ovary Syndrome. Reprod. Sci. 2022, 1, 1-11. [CrossRef]

11. Chen, X.; Koivuaho, E.; Piltonen, T.T.; Gissler, M.; Lavebratt, C. Reply: Association of Maternal Polycystic Ovary Syndrome or Anovulatory Infertility with Obesity and Diabetes in Offspring: A Population-Based Cohort Study. Hum. Reprod. 2021, 37, 193-194. [CrossRef]

12. Kałużna, M.; Człapka-Matyasik, M.; Wachowiak-Ochmańska, K.; Moczko, J.; Kaczmarek, J.; Janicki, A.; Piątek, K.; Ruchała, M.; Ziemnicka, K. Effect of central obesity and hyperandrogenism on selected inflammatory markers in patients with PCOS: A WHtR-matched case-control study. J. Clin. Med. 2020, 9, 3024. [CrossRef]

13. Firoozabadi, A.D.; Firouzabadi, R.D.; Eftekhar, M.; Bafghi, A.S.T.; Shamsi, F. Maternal and neonatal outcomes among pregnant women with different polycystic ovary syndrome phenotypes: A cross-sectional study. Int. J. Reprod. Biomed. 2020, 18, 339. [CrossRef] [PubMed]

14. Liu, S.; Mo, M.; Xiao, S.; Li, L.; Hu, X.; Hong, L.; Wang, L.; Lian, R.; Huang, C.; Zeng, Y.; et al. Pregnancy outcomes of women with polycystic ovary syndrome for the first in vitro fertilization treatment: A retrospective cohort study with 7678 patients. Front. Endocrinol. 2020, 11, 1. [CrossRef] [PubMed]

15. Stener-Victorin, E.; Deng, Q. Epigenetic inheritance of polycystic ovary syndrome-Challenges and opportunities for treatment. Nat. Rev. Endocrinol. 2021, 17, 521-533. [CrossRef] [PubMed] 
16. Stener-Victorin, E.; Padmanabhan, V.; Walters, K.A.; Campbell, R.E.; Benrick, A.; Giacobini, P.; Dumesic, D.A.; Abbott, D.H. Animal Models to Understand the Etiology and Pathophysiology of Polycystic Ovary Syndrome. Endocr. Rev. 2020, 41, bnaa010. [CrossRef] [PubMed]

17. Murrin, C.M.; Kelly, G.E.; Tremblay, R.; Kelleher, C.C. Body mass index and height over three generations: Evidence from the Lifeways cross-generational cohort study. BMC Public Health 2012, 12, 81. [CrossRef]

18. Van Dijk, S.J.; EpiSCOPE, M.O.; Molloy, P.; Varinli, H.; Morrison, J.; Muhlhausler, B.S. Epigenetics and human obesity. Int. J. Obes. 2015, 39, 85-97. [CrossRef]

19. Heijmans, B.T.; Tobi, E.W.; Stein, A.D.; Putter, H.; Blauw, G.J.; Susser, E.S.; Slagboom, P.E.; Lumey, L.H. Persistent epigenetic differences associated with prenatal exposure to famine in humans. Proc. Natl. Acad. Sci. USA 2008, 105, 17046-17049. [CrossRef]

20. Skinner, M.K. Endocrine disruptor induction of epigenetic transgenerational inheritance of disease. Mol. Cell. Endocrinol. 2014, 398, 4-12. [CrossRef]

21. Abbott, D.H.; Dumesic, D.A.; Levine, J.E. Hyperandrogenic origins of polycystic ovary syndrome-Implications for pathophysiology and therapy. Expert Rev. Endocrinol. Metab. 2019, 14, 131-143. [CrossRef]

22. Mimouni, N.E.H.; Paiva, I.; Barbotin, A.-L.; Timzoura, F.E.; Plassard, D.; Le Gras, S.; Ternier, G.; Pigny, P.; Catteau-Jonard, S.; Simon, V.; et al. Polycystic ovary syndrome is transmitted via a transgenerational epigenetic process. Cell Metab. 2021, 33, 513-530. [CrossRef]

23. Dumesic, D.A.; Hoyos, L.R.; Chazenbalk, G.D.; Naik, R.; Padmanabhan, V.; Abbott, D.H. Mechanisms of intergenerational transmission of polycystic ovary syndrome. Reproduction 2020, 159, R1-R13. [CrossRef] [PubMed]

24. Jaeger, K.; Saben, J.L.; Moley, K.H. Transmission of metabolic dysfunction across generations. Physiology 2017, 32, 51-59. [CrossRef] [PubMed]

25. Tian, Y.; Li, J.; Su, S.; Cao, Y.; Wang, Z.; Zhao, S.; Zhao, H. PCOS-GWAS Susceptibility Variants in THADA, INSR, TOX3, and DENND1A are associated with metabolic syndrome or insulin resistance in women with PCOS. Front. Endocrinol. 2020, 11, 274. [CrossRef] [PubMed]

26. Liu, H.; Zhao, H.; Chen, Z.-J. Genome-wide association studies for polycystic ovary syndrome. Semin. Reprod. Med. 2016, 34, 224-229. [CrossRef]

27. Hiam, D.; Moreno-Asso, A.; Teede, H.J.; Laven, J.S.; Stepto, N.K.; Moran, L.J.; Gibson-Helm, M. The genetics of polycystic ovary syndrome: An overview of candidate gene systematic reviews and genome-wide association studies. J. Clin. Med. $2019,8,1606$. [CrossRef]

28. Teede, H.J.; Tay, C.T.; Joham, A.E. Polycystic ovary syndrome: An intrinsic risk factor for diabetes compounded by obesity. Fertil. Steril. 2021, 115, 1449-1450. [CrossRef]

29. Jiang, N.-X.; Li, X.-L. The disorders of endometrial receptivity in PCOS and its mechanisms. Reprod. Sci. 2021, 1-12. [CrossRef]

30. Kara, M.; Ozcan, S.S.; Aran, T.; Kara, O.; Yilmaz, N. Evaluation of endometrial receptivity by measuring HOXA-10, HOXA-11, and leukemia inhibitory factor expression in patients with polycystic ovary syndrome. Gynecol. Minim. Invasive Ther. 2019, 8, 118-122. [CrossRef]

31. Abutorabi, E.S.; Rashidi, B.H.; Irani, S.; Haghollahi, F.; Bagheri, M. Investigation of the FSHR, CYP11, and INSR mutations and polymorphisms in iranian infertile women with Polycystic Ovary Syndrome (PCOS). Rep. Biochem. Mol. Biol. 2021, 9, 470-477. [CrossRef]

32. Baldi, M.; Caserta, D. The genetics of polycystic ovary syndrome. Reprod. Biomed. Online 2006, 13, 10. [CrossRef]

33. Chaudhary, H.; Patel, J.; Jain, N.K.; Joshi, R. The role of polymorphism in various potential genes on polycystic ovary syndrome susceptibility and pathogenesis. J. Ovarian Res. 2021, 14, 1-21. [CrossRef]

34. Kaur, R.; Kaur, T.; Sudhir, N.; Kaur, A. Association Analysis of CYP11A1 variants with polycystic ovary syndrome: A case-control study from North India. Reprod. Sci. 2021, 28, 2951-2960. [CrossRef]

35. Zeng, X.; Xie, Y.-J.; Liu, Y.-T.; Long, S.-L.; Mo, Z.-C. Polycystic ovarian syndrome: Correlation between hyperandrogenism, insulin resistance and obesity. Clin. Chim. Acta 2020, 502, 214-221. [CrossRef]

36. De Leo, V.; Musacchio, M.C.; Cappelli, V.; Massaro, M.G.; Morgante, G.; Petraglia, F. Genetic, hormonal and metabolic aspects of PCOS: An update. Reprod. Biol. Endocrinol. 2016, 14, 1-17. [CrossRef]

37. McGee, E.A. Initial and cyclic recruitment of ovarian follicles. Endocr. Rev. 2000, 21, 200-214. [CrossRef] [PubMed]

38. Otto-Buczkowska, E.; Gliwice, M.S.C.I.; Grzyb, K.; Jainta, N. Polycystic ovary syndrome (PCOS) and the accompanying disorders of glucose homeostasis among girls at the time of puberty. Pediatr. Endocrinol. Diabetes Metab. 2018, 24, 40-44. [CrossRef] [PubMed]

39. Zhang, J.; Yang, M.; Luan, P.; Jia, W.; Liu, Q.; Ma, Z.; Dang, J.; Lu, H.; Ma, Q.; Wang, Y.; et al. Associations between cytochrome P450 (CYP) gene single-nucleotide polymorphisms and second-to-fourth digit ratio in chinese university students. Med Sci. Monit. 2021, 27, e930591-1. [CrossRef]

40. Di Nardo, G.; Zhang, C.; Marcelli, A.G.; Gilardi, G. Molecular and structural evolution of cytochrome P450 aromatase. Int. J. Mol. Sci. 2021, 22, 631. [CrossRef] [PubMed]

41. Xia, J.; Liu, F.; Wu, J.; Xia, Y.; Zhao, Z.; Zhao, Y.; Ren, H.; Kong, X. Clinical and genetic characteristics of $17 \alpha-$ Hydroxylase/17, 20-Lyase Deficiency: C.985_987delTACinsAA mutation of CYP17A1 prevalent in the chinese han population. Endocr. Pract. 2021, 27, 137-145. [CrossRef] 
42. Wang, M.; Strand, M.J.; Lanser, B.J.; Santos, C.; Bendelja, K.; Fish, J.; Esterl, E.A.; Ashino, S.; Abbott, J.K.; Knight, V.; et al. Expression and activation of the steroidogenic enzyme CYP11A1 is associated with IL-13 production in T cells from peanut allergic children. PLoS ONE 2020, 15, e0233563. [CrossRef]

43. Goldstone, J.; Sundaramoorthy, M.; Zhao, B.; Waterman, M.R.; Stegeman, J.J.; Lamb, D.C. Genetic and structural analyses of cytochrome P450 hydroxylases in sex hormone biosynthesis: Sequential origin and subsequent coevolution. Mol. Phylogenet. Evol. 2016, 94, 676-687. [CrossRef] [PubMed]

44. Gharani, N.; Waterworth, D.M.; Batty, S.; White, D.; Gilling-Smith, C.; Conway, G.S.; McCarthy, M.; Franks, S.; Williamson, R. Association of the steroid synthesis gene Cyp11a with polycystic ovary syndrome and hyperandrogenism. Hum. Mol. Genet. 1997, 6, 397-402. [CrossRef] [PubMed]

45. Diamanti-Kandarakis, E.; Bartzis, M.; Bergiele, A.T.; Tsianateli, T.C.; Kouli, C.R. Microsatellite polymorphism (tttta)n at -528 base pairs of gene CYP11 $\alpha$ influences hyperandrogenemia in patients with polycystic ovary syndrome. Fertil. Steril. 2000, 73, 735-741. [CrossRef]

46. Pusalkar, M.; Meherji, P.; Gokral, J.; Chinnaraj, S.; Maitra, A. CYP11A1 and CYP17 promoter polymorphisms associate with hyperandrogenemia in polycystic ovary syndrome. Fertil. Steril. 2009, 92, 653-659. [CrossRef]

47. Zhang, C.-W.; Zhang, X.-L.; Xia, Y.-J.; Cao, Y.-X.; Wang, W.-J.; Xu, P.; Che, Y.-N.; Wu, X.-K.; Yi, L.; Gao, Q.; et al. Association between polymorphisms of the CYP11A1 gene and polycystic ovary syndrome in Chinese women. Mol. Biol. Rep. 2012, 39, 8379-8385. [CrossRef] [PubMed]

48. Abdel-Mageed, W.S.; Dabous, E.; Gerguis, A. Association between polymorphisms of the CYP11A1 gene and polycystic ovary syndrome in egyptian female. Res. J. Appl. Biotechnol. 2016, 2, 19-28. [CrossRef]

49. Liu, T.; Huang, Y.; Lin, H. Estrogen disorders: Interpreting the abnormal regulation of aromatase in granulosa cells (Review). Int. J. Mol. Med. 2021, 47, 1-12. [CrossRef]

50. Zaidi, S.K.; Shen, W.-J.; Cortez, Y.; Bittner, S.; Bittner, A.; Arshad, S.; Huang, T.-T.; Kraemer, F.B.; Azhar, S. SOD2 deficiency-induced oxidative stress attenuates steroidogenesis in mouse ovarian granulosa cells. Mol. Cell. Endocrinol. 2020, 519, 110888. [CrossRef]

51. Reddy, K.R.; Deepika, M.L.N.; Supriya, K.; Latha, K.P.; Rao, S.S.L.; Rani, V.U.; Jahan, P. CYP11A1 microsatellite (tttta)n polymorphism in PCOS women from South India. J. Assist. Reprod. Genet. 2014, 31, 857-863. [CrossRef]

52. Mohammed, A.; Hasan, J.; Joseph, D.N. Association Between Polycystic Ovary Syndrome and Polymorphisms of CYP11A Gene Among Sample of Iraqi Women Introduction: Molecular Analysis: Gene selection Polymerase chain reaction (PCR). J. Univ. Shanghai Sci. Technol. 2020, 22, 712-725.

53. Jiao, X.; Chen, W.; Zhang, J.; Wang, W.; Song, J.; Chen, D.; Zhu, W.; Shi, Y.; Yu, X. Variant Alleles of the ESR1, PPARG, HMGA2, and MTHFR genes are associated with polycystic ovary syndrome risk in a chinese population: A case-control study. Front. Endocrinol. 2018, 9, 504. [CrossRef] [PubMed]

54. Asuncioón, M.; Calvo, R.M.; Millaán, J.L.S.; Sancho, J.; Avila, S.; Escobar-Morreale, H.F. A prospective study of the prevalence of the polycystic ovary syndrome in unselected caucasian women from Spain. Clin. Endocrinol. Metab. 2000, 85, 2434-2438. [CrossRef]

55. Millán, J.S. Role of the pentanucleotide (tttta)n polymorphism in the promoter of the CYP11a gene in the pathogenesis of hirsutism. Fertil. Steril. 2001, 75, 797-802. [CrossRef]

56. Li, T.; Guijin, Z. Role of the pentanucleotide (tttta)n polymorphisms ofCYP11 $\alpha$ gene in the pathogenesis of hyperandrogenism in chinese women with polycystic ovary syndrome. J. Huazhong Univ. Sci. Technol. 2005, 25, 212-214. [CrossRef] [PubMed]

57. Hao, C.F.; Bao, H.C.; Zhang, N.; Gu, H.E.; Chen, Z.J. Evaluation of association between the CYP11 $\alpha$ promoter pen-tannucleotide (TTTTA)n polymorphism and polycystic ovarian syndrome among Han Chinese women. Neuroendocrinol. Lett. 2009, $30,56-60$.

58. Pérez, M.S.; Cerrone, G.; Benencia, H.; Márquez, N.; De Piano, E.; Frechtel, G.D. Polymorphism in CYP11alpha and CYP17 genes and the etiology of hyperandrogenism in patients with polycystic ovary syndrome. Medicina 2008, 68, $129-134$.

59. Prazáková, S.; Vanková, M.; Bradnová, O.; Lukásová, P.; Vcelák, J.; Dvoráková, K.; Vondra, K.; Vrbíková, J.; Bendlová, B. (TTTTA), polymorphism in the promoter of the CYP11A1 gene in the pathogenesis of polycystic ovary syndrome. Cas. Lek. Ceskych 2010, $149,520-525$.

60. Yu, M.; Feng, R.; Sun, X.; Wang, H.; Wang, H.; Sang, Q.; Jin, L.; He, L.; Wang, L. Polymorphisms of pentanucleotide repeats (tttta)n in the promoter of CYP11A1 and their relationships to polycystic ovary syndrome (PCOS) risk: A meta-analysis. Mol. Biol. Rep. 2014, 41, 4435-4445. [CrossRef]

61. Shen, W.; Li, T.; Hu, Y.; Liu, H.; Song, M. Common polymorphisms in the CYP1A1 and CYP11A1 genes and polycystic ovary syndrome risk: A meta-analysis and meta-regression. Arch. Gynecol. Obstet. 2013, 289, 107-118. [CrossRef]

62. Gaasenbeek, M.; Powell, B.L.; Sovio, U.; Haddad, L.; Gharani, N.; Bennett, A.; Groves, C.J.; Rush, K.; Goh, M.J.; Conway, G.S.; et al. Large-scale analysis of the relationship between CYP11A promoter variation, polycystic ovarian syndrome, and serum testosterone. J. Clin. Endocrinol. Metab. 2004, 89, 2408-2413. [CrossRef]

63. Rosenfield, R.L.; Barnes, R.B.; Cara, J.F.; Lucky, A.W. Dysregulation of cytochrome P450c17 $\alpha$ as the cause of polycystic ovarian syndrome. Supported in part by grants HD-06308 and Rr-00055 from the United States Public Health Service, Bethesda, Maryland. Fertil. Steril. 1990, 53, 785-791. [CrossRef]

64. Beştaş, A.; Bolu, S.; Unal, E.; Karakaya, A.A.; Eröz, R.; Tekin, M.; Haspolat, Y.K. A rare cause of delayed puberty and primary amenorrhea: $17 \alpha$-hydroxylase enzyme deficiency. Endocrine 2021, 1-7. [CrossRef] [PubMed] 
65. Echiburú, B.; Pérez-Bravo, F.; Maliqueo, M.; Sánchez, F.; Crisosto, N.; Sir-Petermann, T. Polymorphism T $\rightarrow$ C ( -34 base pairs) of gene CYP17 promoter in women with polycystic ovary syndrome is associated with increased body weight and insulin resistance: A preliminary study. Metabolism 2008, 57, 1765-1771. [CrossRef] [PubMed]

66. Mutib, M.T.; Hamdan, F.B.; Al-Salihi, A.R. Effect of CYP19 Gene on Polycystic Ovary Syndrome Phenotype in Iraqi Women. iasj.net. Iraqi J. Med. Sci. 2015, 13, 272-278.

67. Mohammad, M.; Al-Awadi, S.; Omran, M. Association Between Polycystic Ovary Syndrome and Genetic Polymorphisms of CYP 17 Gene in Iraqi Women. Iraqi J. Biothechnol. 2015, 14, 99-110.

68. Kaur, R.; Kaur, T.; Kaur, A. Genetic association study from North India to analyze association of CYP19A1 and CYP17A1 with polycystic ovary syndrome. J. Assist. Reprod. Genet. 2018, 35, 1123-1129. [CrossRef]

69. Diamanti-Kandarakis, E.; Bartzis, M.I.; Zapanti, E.D.; Spina, G.G.; Filandra, F.A.; Tsianateli, T.C.; Bergiele, A.T.; Kouli, C.R. Polymorphism $\mathrm{T} \rightarrow \mathrm{C}(-34 \mathrm{bp})$ of gene CYP17 promoter in Greek patients with polycystic ovary syndrome. Fertil. Steril. 1999, 71 , 431-435. [CrossRef]

70. Rahimi, Z.; Mohammadi, E. The CYP17 MSP AI (T-34C) and CYP19A1 (Trp39Arg) variants in polycystic ovary syndrome: A case-control study. Int. J. Reprod. Biomed. 2019, 17, 193-200. [CrossRef]

71. Lone, N.M.; Babar, S.; Sultan, S.; Malik, S.; Nazeer, K.; Riaz, S. Association of the CYP17 and CYP19 gene polymorphisms in women with polycystic ovary syndrome from Punjab, Pakistan. Gynecol. Endocrinol. 2021, 37, 456-461. [CrossRef]

72. Ashraf, S.; Rasool, S.U.A.; Nabi, M.; Ganie, M.A.; Jabeen, F.; Rashid, F.; Amin, S. CYP17 gene polymorphic sequence variation is associated with hyperandrogenism in Kashmiri women with polycystic ovarian syndrome. Gynecol. Endocrinol. 2021, 37, 230-234. [CrossRef]

73. Wang, L.; Niu, Y.-M.; Wu, S.-S.; Zhang, C.; Zhou, L.; Zuo, H.-X.; Wang, P. A study on the association between polymorphisms in the cytochrome P450 family 17 subfamily a member 1 gene region and type 2 diabetes mellitus in han chinese. Front. Endocrinol. 2018, 9, 323. [CrossRef] [PubMed]

74. Techatraisak, K.; Chayachinda, C.; Wongwananuruk, T.; Dangrat, C.; Indhavivadhana, S.; Rattanachaiyanont, M.; Thongnoppakhun, W. No association between CYP17 -34T/C polymorphism and insulin resistance in Thai polycystic ovary syndrome. J. Obstet. Gynaecol. Res. 2015, 41, 1412-1417. [CrossRef] [PubMed]

75. Unsal, T.; Konac, E.; Yesilkaya, E.; Yilmaz, A.; Bideci, A.; Onen, H.I.; Cinaz, P.; Menevse, A. Genetic polymorphisms of FSHR, CYP17, CYP1A1, CAPN10, INSR, SERPINE1 genes in adolescent girls with polycystic ovary syndrome. J. Assist. Reprod. Genet. 2009, 26, 205-216. [CrossRef] [PubMed]

76. Kahsarmiller, M.; Boots, L.; Bartolucci, A.; Azziz, R. Role of a CYP17 polymorphism in the regulation of circulating dehydroepiandrosterone sulfate levels in women with polycystic ovary syndrome. Fertil. Steril. 2004, 82, 973-975. [CrossRef] [PubMed]

77. Carey, A.H.; Waterworth, D.; Patel, K.; White, D.; Little, J.; Novelli, P.; Franks, S.; Williamson, R. Polycystic ovaries and premature male pattern baldness are associated with one allele of the steroid metabolism gene CYP17. Hum. Mol. Genet. 1994, 3, 1873-1876. [CrossRef] [PubMed]

78. Crocitto, L.E.; Feigelson, H.S.; Yu, M.C.; Kolonel, L.N.; Henderson, B.E.; Coetzee, G.A. A polymorphism in intron 6 of the CYP17 gene. Clin. Genet. 2008, 52, 68-69. [CrossRef]

79. Miyoshi, Y.; Iwao, K.; Ikeda, N.; Egawa, C.; Noguchi, S. Genetic polymorphism in CYP17 and breast cancer risk in Japanese women. Eur. J. Cancer 2000, 36, 2375-2379. [CrossRef]

80. Baek, K.-H.; Park, J.-M.; Lee, E.-J.; Ramakrishna, S.; Cha, D.-H. Association study for single nucleotide polymorphisms in the CYP17A1 gene and polycystic ovary syndrome. Int. J. Mol. Med. 1998, 22, 249-254. [CrossRef]

81. Bardia, A.; Gucalp, A.; Dacosta, N.; Gabrail, N.; Danso, M.; Ali, H.; Blackwell, K.L.; Carey, L.A.; Eisner, J.R.; Baskin-Bey, E.S.; et al. Phase 1 study of seviteronel, a selective CYP17 lyase and androgen receptor inhibitor, in women with estrogen receptor-positive or triple-negative breast cancer. Breast Cancer Res. Treat. 2018, 171, 111-120. [CrossRef]

82. Sun, J.; Zhang, H.; Gao, M.; Tang, Z.; Guo, D.; Zhang, X.; Wang, Z.; Li, R.; Liu, Y.; Sun, W.; et al. Association between CYP17 T-34C rs743572 and breast cancer risk. Oncotarget 2017, 9, 4200-4213. [CrossRef]

83. Ferzoco, R.M.; Ruddy, K.J. The Epidemiology of Male Breast Cancer. Curr. Oncol. Rep. 2015, 18, 1-6. [CrossRef]

84. Effah, C.Y.; Wang, L.; Agboyibor, C.; Drokow, E.K.; Yu, S.; Wang, W.; Wu, Y. Polymorphism in the Androgen Biosynthesis Gene (CYP17), a Risk for Prostate Cancer: A Meta-Analysis. Am. J. Men's Health 2020, 14, 1557988320959984. [CrossRef] [PubMed]

85. Omear, H.A.; Al-assie, A.H. Plymorphism of CYP17 for Polycystic Ovarian Syndrome in Women of Salah Al-Din Provence/Iraq. J. Biotechnol. Res. Cent. 2014, 8, 50-54. [CrossRef]

86. Louwers, Y.; Stolk, L.; Uitterlinden, A.; Laven, J. Cross-ethnic meta-analysis of genetic variants for polycystic ovary syndrome. J. Clin. Endocrinol. Metab. 2013, 98, E2006-E2012. [CrossRef] [PubMed]

87. Bulun, S.E.; Yang, S.; Fang, Z.; Gurates, B.; Tamura, M.; Zhou, J.; Sebastian, S. Role of aromatase in endometrial disease. J. Steroid Biochem. Mol. Biol. 2001, 79, 19-25. [CrossRef]

88. Xita, N.; Georgiou, I.; Lazaros, L.; Psofaki, V.; Kolios, G.; Tsatsoulis, A. The role of sex hormone-binding globulin and androgen receptor gene variants in the development of polycystic ovary syndrome. Hum. Reprod. 2008, 23, 693-698. [CrossRef]

89. Kristensen, L.H.; Prag, J. Human necrobacillosis, with emphasis on lemierre's syndrome. Clin. Infect. Dis. 2000, 31, 524-532. [CrossRef] 
90. Altmäe, S.; Haller, K.; Peters, M.; Saare, M.; Hovatta, O.; Stavreus-Evers, A.; Velthut, A.; Karro, H.; Metspalu, A.; Salumets, A. Aromatase gene (CYP19A1) variants, female infertility and ovarian stimulation outcome: A preliminary report. Reprod. Biomed. Online 2009, 18, 651-657. [CrossRef]

91. Lee, S.-J.; Kim, W.-Y.; Choi, J.-Y.; Lee, S.S.; Shin, J.-G. Identification of CYP19A1 single-nucleotide polymorphisms and their haplotype distributions in a Korean population. J. Hum. Genet. 2010, 55, 189-193. [CrossRef]

92. Setiawan, V.W.; Doherty, J.A.; Shu, X.O.; Akbari, M.R.; Chen, C.; De Vivo, I.; DeMichele, A.; Garcia-Closas, M.; Goodman, M.T.; Haiman, C.A.; et al. Two estrogen-related variants in CYP19A1 and endometrial cancer risk: A pooled analysis in the Epidemiology of Endometrial Cancer Consortium. Cancer Epidemiol. Prev. Biomark. 2009, 18, 242-247. [CrossRef]

93. Wang, L.; Lu, X.; Wang, D.; Qu, W.; Li, W.; Xu, X.; Huang, Q.; Han, X.; Lv, J. CYP19 gene variant confers susceptibility to endometriosis-associated infertility in Chinese women. Exp. Mol. Med. 2014, 46, e103. [CrossRef] [PubMed]

94. Lazaros, L.A.; Hatzi, E.G.; Xita, N.V.; Makrydimas, G.V.; Kaponis, A.I.; Takenaka, A.; Kosmas, I.P.; Sofikitis, N.V.; Stefos, T.I.; Zikopoulos, K.A.; et al. Aromatase (CYP19) gene variants influence ovarian response to standard gonadotrophin stimulation. J. Assist. Reprod. Genet. 2012, 29, 203-209. [CrossRef] [PubMed]

95. Wang, Y.; Zhang, X.-L.; Zhang, C.-W.; Xu, P.; Liang, F.-J.; Che, Y.-N.; Xia, Y.-J.; Cao, Y.-X.; Wu, X.-K.; Wang, W.-J.; et al. SNP rs2470152 in CYP19 is correlated to aromatase activity in Chinese polycystic ovary syndrome patients. Mol. Med. Rep. 2011, 5, 245-249. [CrossRef] [PubMed]

96. Lazaros, L.; Xita, N.; Hatzi, E.; Takenaka, A.; Kaponis, A.; Makrydimas, G.; Sofikitis, N.; Stefos, T.; Zikopoulos, K.; Georgiou, I. CYP19gene variants affect the assisted reproduction outcome of women with polycystic ovary syndrome. Gynecol. Endocrinol. 2013, 29, 478-482. [CrossRef] [PubMed]

97. Xu, P.; Zhang, X.L.; Xie, G.B.; Zhang, C.W.; Shen, S.M.; Cao, Y.X.; Wang, W.J.; Che, Y.N.; Xia, Y.J.; Wu, X.K.; et al. The (TTTA) n polymorphism in intron 4 of CYP19 and the polycystic ovary syndrome risk in a Chinese population. Mol. Biol. Rep. 2013, 40, 5041-5047. [CrossRef]

98. Dou, Q.; Tan, L.; Ma, L.-Y.; Sun, Y.-P. The relationship between the CYP19 alleles rs727479A/C, rs700518A/G, and rs700519C/T and pregnancy outcome after assisted reproductive technology in patients with polycystic ovary syndrome in a Chinese population: A population-based study. Kaohsiung J. Med Sci. 2017, 33, 558-566. [CrossRef]

99. Mehdizadeh, A.; Kalantar, S.M.; Sheikhha, M.H.; Aali, B.S.; Ghanei, A. Association of SNP rs.2414096 CYP19 gene with polycystic ovarian syndrome in Iranian women. Int. J. Reprod. Biomed. 2017, 15, 491-496. [CrossRef]

100. Feng-Jing, L.; Sun, J.; Ge, H.-J.; Cao, Y.-X.; Wu, X.-K.; Liang, F.-J.; Sun, H.-X.; Xiao-Ke, W.; Yi, L.; Wu, Z.-W.; et al. Association between CYP19 gene SNP rs2414096 Polymorphism and polycystic ovary syndrome in Chinese women. BMC Med. Genet. 2009, 10, 139. [CrossRef]

101. Xita, N.; Lazaros, L.; Georgiou, I.; Tsatsoulis, A. CYP19 gene: A genetic modifier of polycystic ovary syndrome phenotype. Fertil. Steril. 2010, 94, 250-254. [CrossRef]

102. Che, X.; Jian, F.; Chen, C.; Liu, C.; Liu, G.; Feng, W. PCOS serum-derived exosomal miR-27a-5p stimulates endometrial cancer cells migration and invasion. J. Mol. Endocrinol. 2020, 64, 1-12. [CrossRef]

103. Lees, B.; Hampton, J.M.; Trentham-Dietz, A.; Newcomb, P.; Spencer, R. A population-based study of causes of death after endometrial cancer according to major risk factors. Gynecol. Oncol. 2021, 160, 655-659. [CrossRef] [PubMed]

104. Zhu, T.; Cui, J.; Goodarzi, M.O. Polycystic Ovary Syndrome and Risk of Type 2 Diabetes, Coronary Heart Disease, and Stroke. Diabetes 2020, 70, 627-637. [CrossRef]

105. Ayyob, A.N.; Al-Badran, A.I.; Abood, R.A. Association of TTTA polymorphism in CYP19 gene with endometrial and ovarian cancers risk in Basrah. Gene Rep. 2019, 16, 100453. [CrossRef]

106. Harris, H.R.; Terry, K.L. Polycystic ovary syndrome and risk of endometrial, ovarian, and breast cancer: A systematic review. Fertil. Res. Pract. 2016, 2, 1-9. [CrossRef]

107. Kusum, K.; Patel, S.; Chaube, R.; Ashish, A.; Rai, S. Aromatase gene polymorphism (rs2470152) in Polycystic Ovary Syndrome patients of eastern Uttar Pradesh. J. Clin. Diagn. Res. 2020, 3-8. [CrossRef]

108. Mostafa, R.A.; Al-Sherbeeny, M.M.; Fahmy, A.A.; Farghali, M.M.; Abdel-Fatah, M.A.; Mahran, M.Z. Relation between aromatase gene CYP19 variation and hyperandrogenism in Polycystic Ovary Syndrome Egyptian women. J. Infertil. Reprod. Biol. 2016, $4,1-5$.

109. Araújo, B.S.; Baracat, M.C.P.; Simões, R.D.S.; Nuñes, C.D.O.; Maciel, G.A.R.; Lobo, R.A.; Soares-Jr, J.M.; Baracat, E.C. Kisspeptin Influence on Polycystic Ovary Syndrome-A Mini Review. Reprod. Sci. 2020, 27, 455-460. [CrossRef]

110. Azziz, R.; Carmina, E.; Dewailly, D.; Diamanti-Kandarakis, E.; Escobar-Morreale, H.F.; Futterweit, W.; Janssen, O.E.; Legro, R.S.; Norman, R.; Taylor, A.E.; et al. The Androgen Excess and PCOS Society criteria for the polycystic ovary syndrome: The complete task force report. Fertil. Steril. 2009, 91, 456-488. [CrossRef] 